\title{
Edirne Rüstempaşa Kervansarayı'nın Yeni İşlevinin Değerlendirilmesi
}

\begin{abstract}
Gamze Fahriye ERAYBAT PEHLIVAN*
Sivas Cumhuriyet Üniversitesi, Mimarlık Fakültesi, Mimarlık Bölümü, 58140, Sivas, Türkiye.

*e-mail: geraybat@selcuk.edu.tr

Öz

Değişimin sürekliliğine ayak uyduramayan tarihi yapılar, zamanla işlevini yitirmektedir. İşlevi sona eren yapılar, önce terk edilmekte daha sonra hızlı bir yıkılma sürecine girmektedir. Bu yapıları, kullanılabilir hale getirmek, günlük yaşamın içine dâhil etmek ve yaşatarak korumak için yeniden işlevlendirme yöntemi kullanılmaktadır. Bu çalışmada sürdürülebilir koruma anlayışının bir parçası olarak yeniden işlevlendirmenin önemini vurgulamak, yeniden işlevlendirmeyi teşvik etmek ve tarihi yapılara verilecek/verilmiş çağdaş işlevin yeterliliğini irdelemek amaçlanmaktadır. Bu kapsamda, örnek olarak Edirne Rüstempaşa Kervansarayı́nın yeni işlevini irdelemek ve değerlendirmek hedeflenmektedir. Çalışmada öncelikle yapının tanımı, mimari özellikleri, geçmiş ve günümüz işlevi anlatılmıştır. Edirne Rüstempaşa Kervansarayı'na verilen yeni işlev; konum, mekânsal elverişlilik, mekânsal gereklilik ve mekânlar arası ilişki kurgusu açısından dört farklı çözümlemeyle ele alınmıştır. Belirtilen bu dört çözümleme; güçlü ve zayıf yanları, fırsat ve tehditleri olmak üzere incelenmiştir. SWOT analizi olarak isimlendirilen bu yöntemde, üstünlükler ve fırsatlar, yeniden işlevlendirmenin olumlu yönlerini oluştururken zayıfıklar ve tehditler olumsuz yönlerini meydana getirmektedir. Boyutsal yeterlilik için kaynak araştırması yapılarak boyut ve kapasiteyle ilgili kriterler belirlenmiştir. Belirlenen kriterlere göre mevcut mekânların boyutsal yeterliliği irdelenmiştir. Değerlendirmenin sonucunda otelde lobi, balo salonu, satış ofisleri, restoran, vestiyer ve servis merdiveni gibi mekanların bulunmadığı, bar ve toplantı salonu gibi mekanların yeni işleve elverişli olmadığı, müşteri ve servis sirkülasyonun çakıştığı, resepsiyon bankosunun olması gerekenden daha kısa olduğu, yatak odalarının boyutlarının standartların alt sınırını sağladığı, kahvaltı salonu ve odaların iyi ışık almadığı ortaya çıkmaktadır. Yeni işlevin olumlu ve olumsuz yönleri göz önünde bulundurulduğunda, işlevsel aksaklıklara rağmen yeni işlevin sürdürülebilir korumaya katkıları ile ekonomik, çevresel, sosyal, tarihi ve kültürel katkıları bulunmaktadır.
\end{abstract}

Anahtar Kelimeler: Rüstempaşa Kervansarayı, yeniden işlevlendirme, koruma

\section{The Evaluation of Edirne Rüstempaşa Caravanserai Reusing}

\begin{abstract}
Historical buildings that could not keep up with the continuity of change lose their functions by time. As for the buildings whose functions end, they are firstly abandoned and then their destruction process begins. Reusing method is used to make these buildings usable, include them into daily life and conserve. In this study, it is aimed to mention the importance of reusing as a part of sustainable conservation understanding, to encourage reusing and examine the sufficiency of contemporary function that has been given or will be given to historical buildings.
\end{abstract}

Atıf: Eraybat Pehlivan, G. F. (2018). Edirne Rüstempaşa Kervansarayı'nın Yeni İşlevinin Değerlendirilmesi. Mimarlık Bilimleri ve Uygulamaları Dergisi (MBUD), 3 (2), 1-20. DOI: $\underline{10.30785 / \mathrm{mbud} .370896}$ 
In this content, as an example, it is aimed to examine and evaluate new function of Edirne Rustempasa Caravanserai. Firstly, the definition, architectural features, the past and contemporary function of the building are explained in the paper. SWOT analysis is used as an analysis method in the study. The new function given to Edirne Rustempasa Caravanserai is dealt with as strengths, weaknesses, opportunities and threats with four different analyses as location, spatial convenience and necessity, and relationship among spaces. While superiorities and opportunities are positive aspects of re-using, weaknesses and threats are negative aspects. Criteria related to dimension and capacity are determined by researching sources for dimensional sufficiency. According to determined criteria, dimensional sufficiency of available spaces are examined. As a result of evaluation, it is seen that there are not any spaces such as lobbies, ball rooms, sales offices, restaurants, coat checks and service stairs in the hotel and spaces used for bar and meeting room are not suitable for their functions. What is more, clients and service circulation overlap and reception counter is shorter than it should be. Also, it is seen that dimensions of bedrooms provides lower standard limits and breakfast hall and rooms cannot get enough light. When positive and negative results of reusing are taken into consideration, there are contributions to sustainable conservation and economic, environmental, historical, social and cultural contributions of reusing although functional problems.

Keywords: Rüstempaşa Caravanserai, reusing, conservation

\section{Giriş}

Mimari miras, insan ömründen daha uzun bir yaşam süresine sahip, kültürel bir öğe ve toplumsal bir üründür (Cassar, 2009). Bu ürünlerin bir kısmı (cami, kilise, sinagog, çeşme gibi) özgün işlevini devam ettirmesine rağmen saray, medrese, tabhane, hamam, darüşşifa, kervansaray, han gibi yapılar özgün işlevini yitirmektedir; konut, sultani, idadi gibi yapılar da işlevsel olarak eskimektedir (Ahunbay, 2009; Altınoluk, 1998). Özgün işlevi hala devam eden yapılar hariç diğer tarihi yapılar, zamanla değişen ihtiyaçlara uygun olarak ilk yapılış amacından farklı amaçlarla ya da işlevsel güncellemeyle kullanılmaktadır (Ahunbay, 2009).

Yeniden kullanım olarak isimlendirilen bu kavram, geniş kapsamlı anlamıyla, bir yapının yeni koşullara ve ihtiyaçlara göre günümüz standartlarına uyum sağlayabilmesi için kapasitesini, işlevi veya performansını değiştiren müdahale olarak tanımlanmaktadır (Douglas, 2006: 1). Özellikle İngiltere, Birleşik Devletler, Kanada, Hong Kong, Kuzey Afrika ve Avustralya gibi ülkeler başta olmak üzere, tüm dünyada tarihi yapıların yeniden kullanımı, hükümet politikası ve sürdürülebilir kalkınmayı sağlamanın temelleri olarak görülmektedir (Conejos vd., 2011; Kincaid, 2002).

Ekonomik açıdan bakıldığında aslında yapıların tekrar kullanılma maliyetleri, yıkım ve rekonstrüksiyon maliyetlerinden daha düşüktür (Douglas, 2006).

Artan arsa fiyatları, restorasyon amacıyla yapılan strüktürel müdahalelerin getirdiği maliyetler, bu mali kaynakların temin edilme güçlüğü, yapıların zamanla işlevsiz kalması ve yapılardan ekonomik kazanç sağlama çabası göz önünde bulundurulduğunda, yeniden kullanımın haklı gerekçeleri bulunmaktadır (Kuban, 2000).

Mimari ve tarihi açıdan önem arz eden yapıların yeniden kullanımıyla bir yandan bakım ve onarım yapılırken öte yandan yapılar kaybettiği prestiji yeniden kazanmaktadır. Yeniden kullanım, harap haldeki bir tarihi yapının tekrar hayata kazandırılması yoluyla bölgede bir canlanma meydana getirmektedir (Douglas, 2006). Yapıların sürekli bakımının yapılması da onları yıkılma sürecinden kurtarmaktadır. Yani yeniden işlevlendirme tarihi yapıların korunması için bir araçtır (Ahunbay 2009).

Değerli bir kültürel mirasın geri dönüştürülmesinin sosyal, kültürel ve ekonomik avantajlar ile birlikte karbon emisyonlarının azaltılması ve enerji tasarrufu gibi çevresel faydaları da vardır (Yung ve Chan, 2012). Yeniden kullanımla yapı üretimi yüzünden doğal kaynakların tükenme ve atık üretme oranı azalmaktadır (Langston, 2008; Langston ve Shen, 2007). Bu çevresel katkılar, yeniden kullanımı, sürdürülebilir kalkınmanın önemli bir bileşeni haline getirmektedir (Yung ve Chan, 2012).

Yirmi birinci yüzyılda ortaya çıkan zorluklar ve stratejiler göz önünde bulundurulduğunda ve toplumdaki bazı temel gelişmeler, koruma kavramları ve mesleğimizin ışığında bir değerlendirme 
yapıldığında (Cassar, 2009), mimari mirasın sürdürülebilir korunması için yeniden kullanım, bir gereklilik haline gelmiştir (Aydın ve Okuyucu, 2009).

Bu çalışmada, günümüz konfor koşullarını sağlayamayan kervansarayların kullanım dışı kalması sonucu harap olmasına engel olabilmek için yeni bir işlevin verilmesini teşvik etmek ve verilen yeni işlevin yapı için uygun olup olmadığını araştırmak amaçlanmaktadır.

Çalışma kapsamında, otel işlevi verilen Edirne Rüstempaşa Kervansarayı'nın korunmuşluk durumu, restitüsyon ve restorasyon sorunları yerine, yeni işlevinin yapı için uygun olup olmadığını incelemek hedeflenmiştir.

\section{Materyal ve Yöntem}

Klasik Osmanlı Dönemi, Mimar Sinan yapısı olan Edirne Rüstempaşa Kervansarayı'nın tanımlanması, mekânların eski ve yeni kullanımlarının tespit edilmesi için materyal olarak kervansarayın çizimlerinden ve fotoğraflarından yararlanılmıştır. Ayrıca yerinde gözlem ve incelemelerde bulunulmuştur.

Çalışmada analiz yöntemi olarak SWOT analizinden faydalanılmıştır. SWOT analizi, karar vermeyi gerektiren bir durumun ya da bir projenin güçlü (Strengths) ve zayıf (Weaknesses) yönlerini, fırsat (Opportunities) ve tehditlerini (Threats) değerlendirmeyi sağlayan stratejik bir tekniktir. (Hay ve Castilla, 2006). SWOT analizi, eskiden işletmeler için kullanılan bir yöntemken günümüzde eğitim bilimleri, turizm, coğrafya, mühendislik ve mimarlık gibi alanlarda da kullanılmaktadır.

Bu analizde, Edirne Rüstempaşa Kervansarayı'na verilen yeni işlev; konum, mekânsal elverişlilik, mekânsal gereklilik ve mekânlar arası ilişki kurgusu olmak üzere dört farklı çözümlemeyle güçlü (üstün) ve zayıf yanları, fırsat ve tehditleri olmak üzere ele alınmıştır. Üstünlükler ve fırsatlar, yeniden işlevlendirmenin olumlu yönlerini oluştururken zayıflıklar ve tehditler olumsuz yönlerini meydana getirmektedir. Boyutsal yeterlilik için kaynak araştırması yapılarak boyut ve kapasiteyle ilgili kriterler belirlenmiştir. Belirlenen kriterlere göre mevcut mekânların boyutsal yeterliliği irdelenmiştir.

\section{Bulgular ve Tartışma}

\subsection{Yapının Kısa Tarihçesi ve Konumu}

Han ve kervansaray birbirinden farklı kavramlar olup han daha çok şehir merkezinde yer alan, kervansaray ise uzak menzillerde yer alan konaklama yapısıdır (Güran, 1978). Büyük kervan yolu güzergâhında yer alan şehirlerde, kervanların şehir içinde konaklaması amacıyla yapılan hanlara da "kervansaray" denilmektedir (Kuban, 2007). Osmanlı orta kolu olarak bilinen "İstanbul-Belgrad" yolunun geçtiği Edirne'de, de konaklama yapıları "kervansaray" olarak isimlendirilmektedir (Şekil 3.1). Bu sebeple yapıya kervansaray denilmektedir.

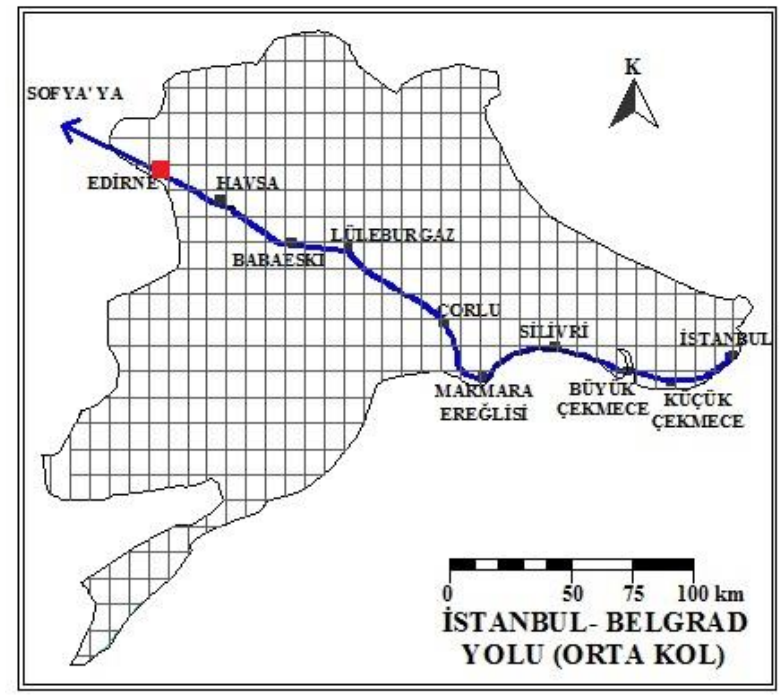

Şekil 3.1. İstanbul- Belgrad Yolu ve Edirne (Pehlivan, 2010) 
Yapı, Kanuni Sultan Süleyman'ın sadrazamı Rüstem Paşa tarafından yaptırıldığından "Rüstempaşa Kervansarayı" olarak anılmaktadır (Cantay, 1988; Çakırlar, 1974) Büyük kervansaray ve küçük kervansaray olmak üzere iki birimden oluşan yapı, H.968 (M.1560-1561) yılında inşa edilmiştir (Akçıl, 2008). Büyük kervansarayın Mimar Sinan tarafından yapıldığı kesindir; ancak küçük kervansarayın kim tarafından yapıldığı bilinmemektedir (Çakırlar, 1974).

A89 numaralı envantere kayıtlı yapı; Edirne ili, Sabuni Mahallesi, 24 pafta, 419 adada yer almaktadır (Edirne Belediyesi Arşivi, 2011). Adayı tamamen kaplayan yapının ana girişi, kuzeybatıdaki Iki Kapılı Han Caddesindendir.

Tarihi kent çekirdeğinde yer alan kervansarayın kuzeyinde Eski Cami, kuzeybatısında Illhan Koman Parkı, parkın hemen arkasında Bedesten ve Tahmis Hamamı bulunmaktadır. Yapının kuzeydoğusunda iş merkezleri, güneydoğusunda otopark ve iş merkezleri, güneybatısında, otopark, iş merkezleri ve bir otel yer almaktadır. Yapının yakın çevresinde küçük oteller bulunmaktadır (Şekil 3.2).

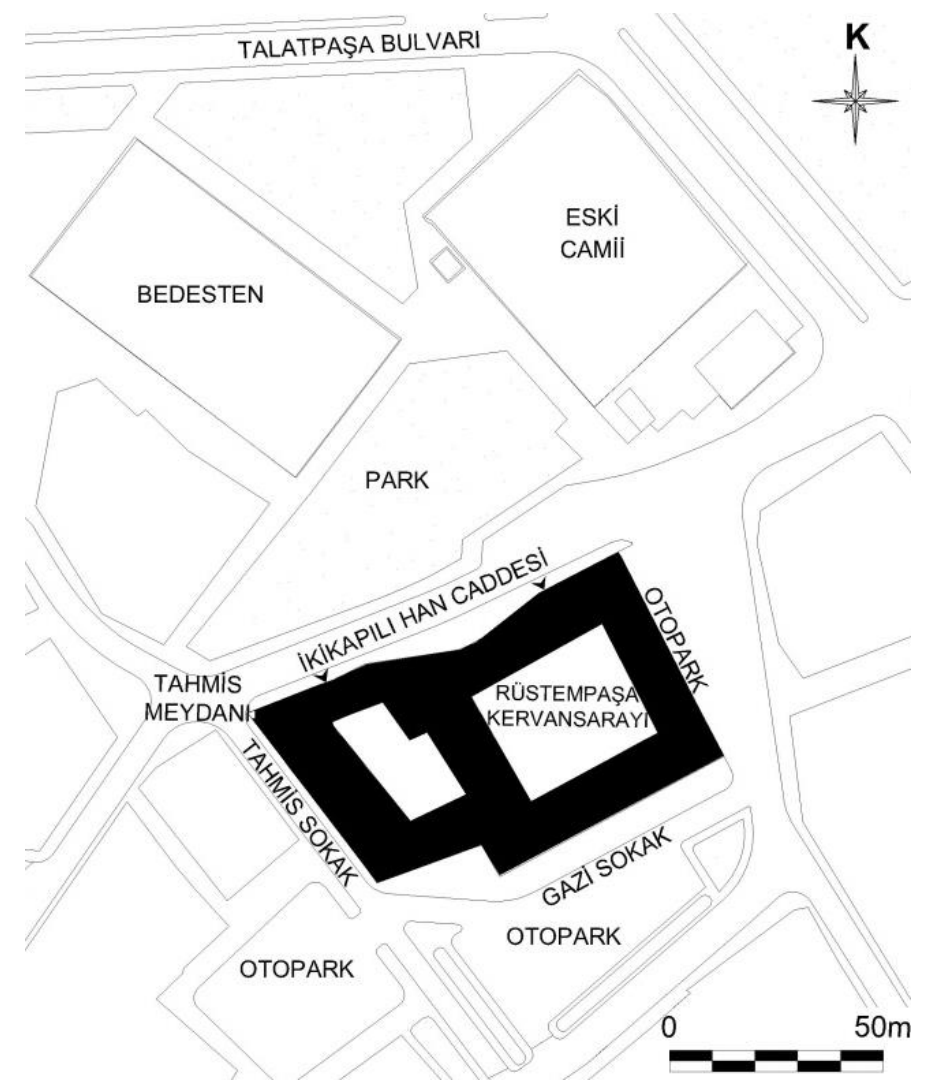

Şekil 3.2. Rüstempaşa Kervansaray Otel'in yakın çevresi (Edirne Belediyesi Arşivi, 2011)

Dönemin en önemli konaklama yapılarından biri olan kervansaray, uzun yıllarca orijinal işlevinde kullanılmıştır. 1921 yılında bankerlerin iş merkezi, 1930'larda zengin tüccarların ticarethanesi, íkinci Dünya Savaşı'ndan sonra kozaların satıldığı bir han olarak kullanılmıştır (Eraybat, 2011; Onur, 2006).

Kervan kültürünün bitmesi, yeni ulaşım ağlarının ve araçlarının ortaya çıkması, konfor koşullarının değişmesi, ekonomik kaynakların kıtlığı vb. sebeplerle gerekli bakım ve onarım çalışmaları yapılamayan kervansaray, harap olmuştur. Daha sonra yapının mülkiyetini üzerinde bulunduran Vakıflar Genel Müdürlüğü, ilk kez 1960-61 yıllarında restorasyon çalışmalarına başlamıştır. 1964-65 yılları arasında restorasyon çalışmaları devam etmiş, 1966 yılında otel işlevine dönüştürülmesine karar verilmiştir. Yeniden işlevlendirme projesi hazırlanarak 150 yataklı bir otel olarak 1972'de hizmete açılmıştır (Çakırlar, 1974). Bu projeyle mimar Ertan Çakırlar, 1980 yıında Ağa Han Mimarlık Ödülü'nü almıştır (Mıhlayanlar ve Yardımlı, 2006). Kervansaray, 1980-1988 yılları arasında kullanılmamıştır (Küçükkaya, 1990). 1988'den günümüze kadar otel işlevini sürdürmektedir. 


\subsection{Mimari Özellikler}

Edirne Rüstempaşa Kervansarayı, Mimar Sinan'ın diğer kervansaraylarından farklı olarak külliyenin içinde değil, tek başına bir konaklama yapısı olarak inşa edilmiştir (Şekil 3.3). Bunun sebebi, konumu itibariyle kervansarayın birçok intiyacının kent merkezinden karşılanabiliyor olmasıdır. Bunun dışında kervansaray içinde çözülmesi gereken temizlik, pişirme, yemek yeme gibi eylemlerin gerçekleştirildiği mekânlar, yatma hacimlerinden bağımsız bir şekilde düzenlenmiştir (Cantay, 1988). Bir başka değişle, yatma birimleriyle hizmet birimleri fonksiyonel olarak birbirinden ayrılmıştır. Buna göre büyük kervansarayın zemin katı ve üst katı misafirlerin konaklaması için, küçük kervansarayın zemin katı ahır, mutfak ve depo amaçlı, üst katı hizmetlilerin konaklaması için kullanılmıştır (Süman, 2000) (Şekil 3.4, 3.5).

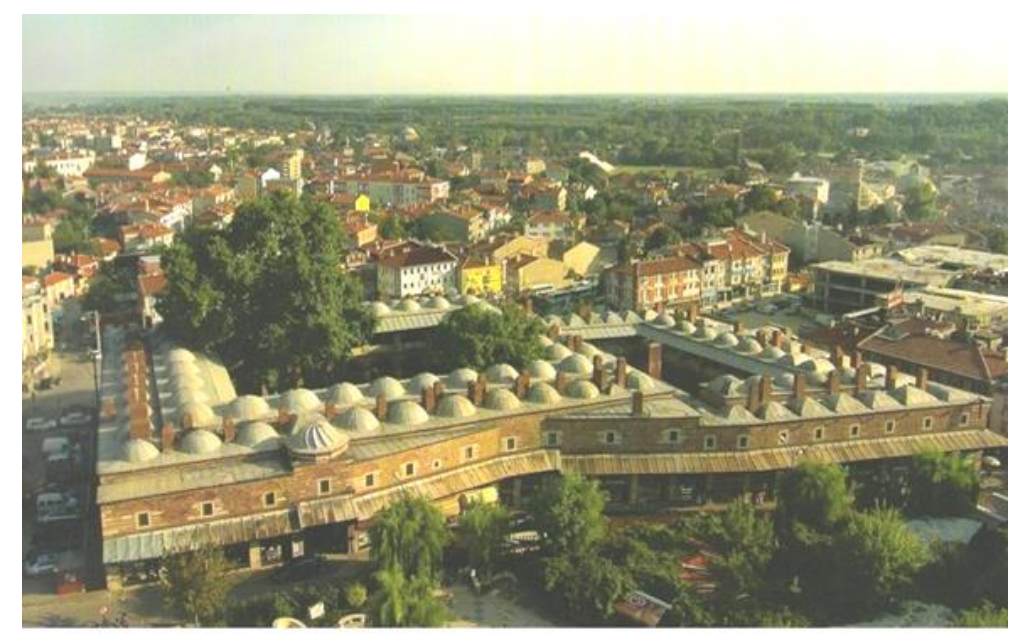

Şekil 3.3. Rüstempaşa Kervansarayı genel görünümü (Eraybat, 2011)

Birçok han ve kervansarayda, avlu hariç, hayvanlar ve insanlar aynı kapalı mekânın içinde bulunmaktaydı (Edirne Deveci Han, Edirne Ekmekçizade Ahmetpaşa Kervansarayı, Konya Horozlu Han, Burdur Susuz Han gibi). Edirne Rüstempaşa Kervansarayı'nda hayvanların bulunduğu yer ile insanların kaldığı yer mekân olarak hatta farklı binalarla birbirinden ayrılmıştır (Şekil 3.4, 3.5).

Yukarıda açıklanan bu plan özellikleri, kervansarayın, gelişmiş bir plan şemasına sahip olduğunu göstermektedir. Osmanlı İmparatorluğu'nun Yükseliş Döneminin vermiş olduğu prestijin yansıması, Mimar Sinan'ın mimari tasarım denemeleri, Edirne'nin batıya açılan bir kapı ve kervan yolu üzerindeki büyük şehirlerden biri olması, bu tasarım anlayışının gelişmesinde etkili olmuş olabilir. 


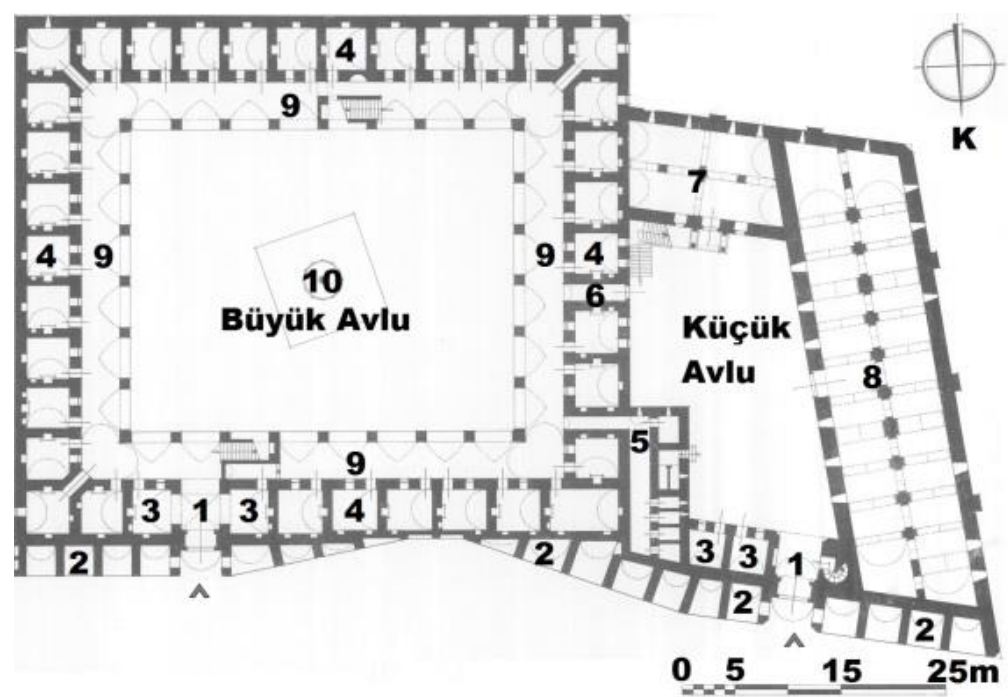

\begin{tabular}{|c|c|c|c|}
\hline 1-Girişler & 2-Dükkânlar & $\begin{array}{l}\text { 3-Han Gör. } \\
\text { Odaları }\end{array}$ & 4-Odala \\
\hline 5-Tuvaletler & 6-Geçit & 7-Mutfak/Depo & 8-Ahır \\
\hline 9-Revaklar & 10- Köşk Mescidi(Mevcut değil) & & \\
\hline
\end{tabular}

Şekil 3.4. Rüstempaşa Kervansarayı zemin kat planı (Ülgen, 1948 'den düzenlenmiştir.)

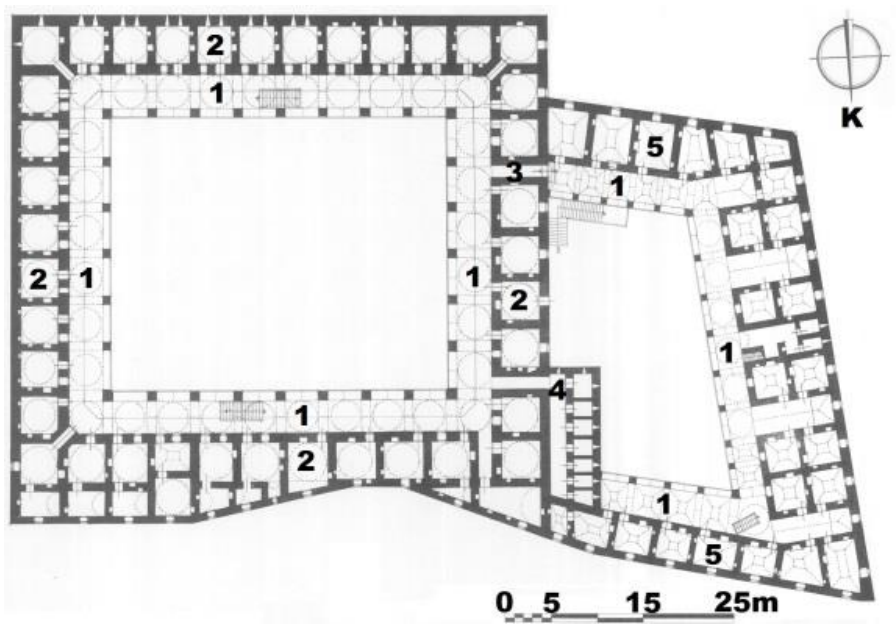
1- Revaklar
2- Odalar
3- Geçit
4-Tuvaletler
5-Hizmetli/Seyis Odaları

Şekil 3.5. Rüstempaşa Kervansarayı üst kat planı (Ülgen, 1948'den düzenlenmiştir.)

Tasarımda dikkat çeken bir diğer husus da yapının plan şeklinin düzgün bir geometriye sahip olmamasıdır. Organik sokak dokusuna uyum sağlayan bir tasarım anlayışı kabul edilmiştir (Küçükkaya, 1990). 


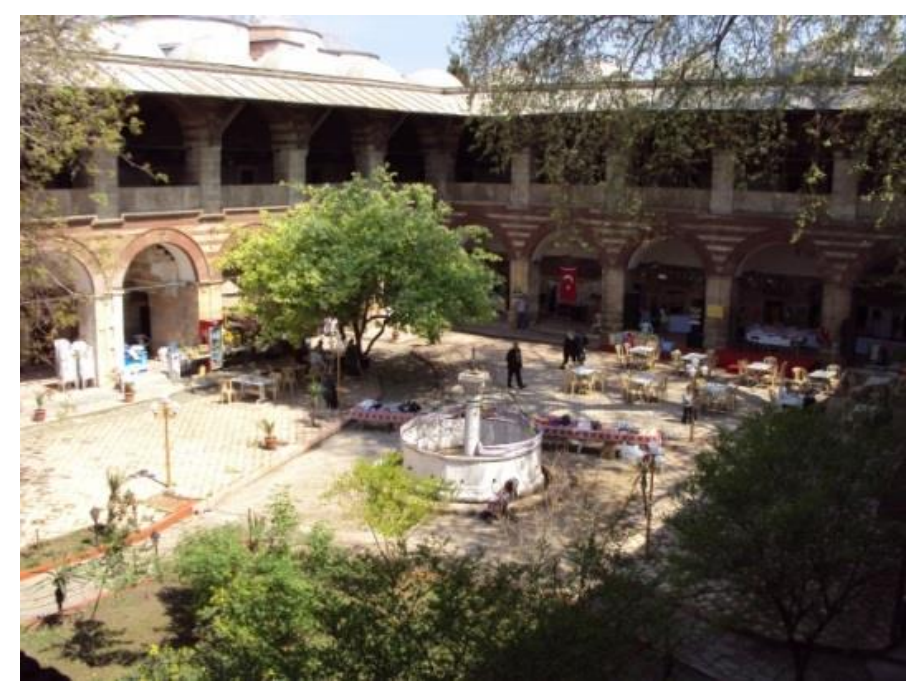

Şekil 3.6. Rüstempaşa Kervansaray Otel'in büyük avlusu

Büyük kervansaraydan girildiğinde muhtemelen han görevlilerine ait sağda ve solda olmak üzere iki adet oda yer almaktadır (Eraybat, 2011). Girişten revaklara geçildiğinde biri hemen sağda diğeri de karşıda olmak üzere iki adet merdiven bulunmaktadır (Şekil 3.4, 3.5). Avlunun hemen ortasında bir şadırvan vardır; ancak yapılan araştırmalar sonucunda, yapının özgün halinde, ortada bir köşk mescidinin bulunduğu bilinmektedir. Bu mescit, 1877-1878 Osmanlı-Rus savaşında yıkılmıştır (Çakırlar, 1974).

Dikdörtgen büyük avluyu çevreleyen sütun ve kemerlerin oluştuğu revaklar, her iki katta da mevcuttur. Zemin kat yuvarlak kemerli, üst kat sivri kemerli revaklardan meydana gelmektedir (Şekil 3.6, 3.7). Revakların arkalarında konaklama fonksiyonuna ayrılmış odalar, odaların içlerinde nişler ve ocaklar yer almaktadır. Büyük kervansarayın üst katındaki odalardan ön cepheye bakanlar, iç içe geçilen iki odadan oluşmaktadır. Bu ikili odalardan revaklara yakın olanlar revaklardan aydınlanırken, ön cephe tarafındakiler bu cepheden ışık almaktadır. Bunların dışındaki odaların birçoğunda iç avluya ya da dışarıya bakan pencereler veya mazgallar vardır. Pencere ya da mazgal bulunmayan birkaç oda, hiç ışık almamaktadır (Şekil 3.4, 3.5).

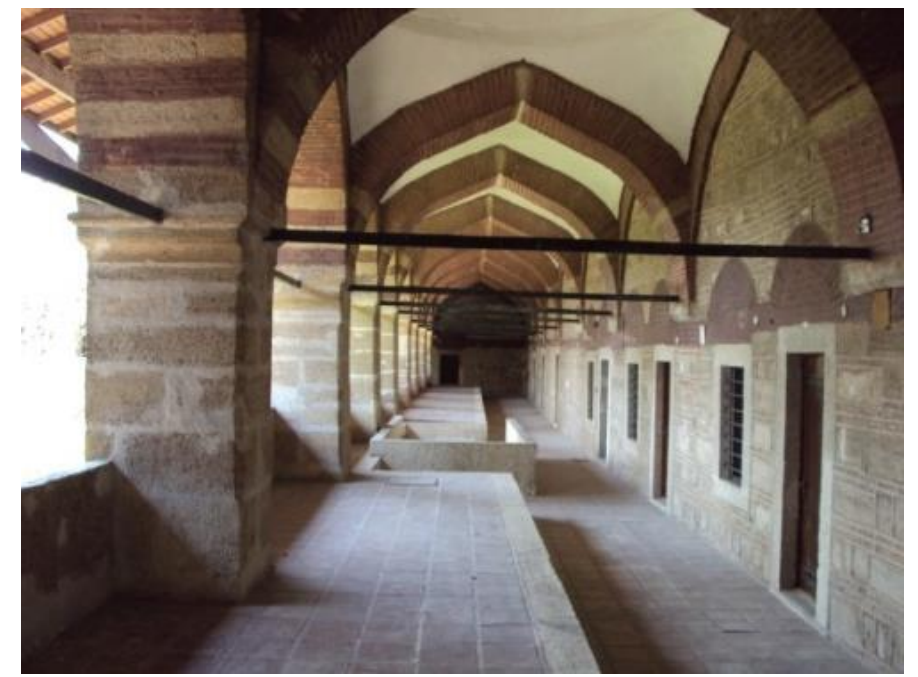

Şekil 3.7. Rüstempaşa Kervansaray Otel'in revaklı galerisi (23.04.2010)

Küçük kervansarayın girişinin sağında dairesel bir merdiven, solunda muhtemelen han görevlilerine ait iki oda bulunmaktadır (Şekil 3.14), (Eraybat, 2011). Avlunun güneybatısındaki geniş mekân ahır, güneydoğusundaki küçük mekân mutfak ve depo olarak kullanılmıştır. Avlunun kuzeydoğu duvarında orijinal çeşme ve tuvaletler vardır (Çakırlar, 1974). Süman (2000), üst kattaki konaklama odalarının seyis ve diğer hizmetlilere ait olduğunu ifade etmektedir. 
Kervansarayın ana girişi muhtemelen büyük kervansaray kısmındandır. Çünkü bu giriş, düşey kotta dükkân saçaklarından yükseltilmiş ve üstü dilimli ve burmalı bir kubbeyle örtülerek vurgulanmıştır. Aynı cephede küçük kervansaray tarafında daha mütevazı bir giriş daha bulunmaktadır. Bu cepheye formunu veren dükkânlar, sıra dizi halinde ve eyvan şeklinde düzenlenmiştir. Cepheyi oluşturan duvar, kesme taş üstüne almaşık duvar örgüsünden oluşmaktadır. Üst katta pencerelerin etrafında, kesme taştan dikdörtgen pencere sövesi ve söve üstünde sivri tuğla kemer ve alınlık yer almaktadır (Şekil 3.8).

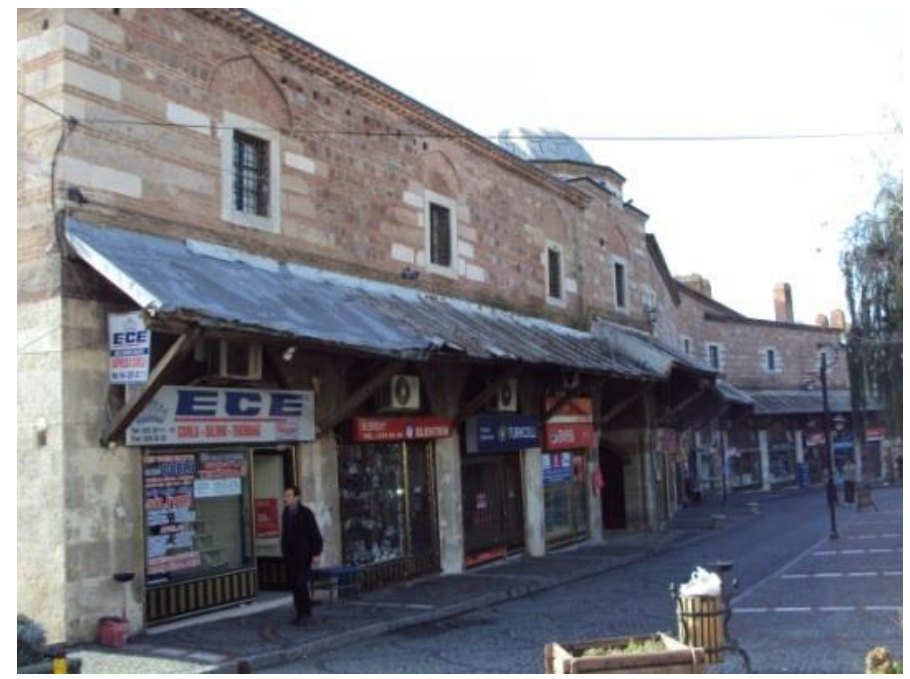

Şekil 3.8. Rüstempaşa Kervansaray Otel'in giriş cephesi

Yapının kuzeybatı cephesi, köşeleri kesme taş, diğer yerleri almaşık duvar olmak üzere kurgulanmıştır. Bu cephede de dikdörtgen söveli pencereler ve mazgal pencere yer almaktadır. Güneybatı ve güneydoğu cephesinde, almaşık duvarda tuğla sivri kemerli ve kemersiz dikdörtgen söveli pencereler mevcuttur. Ayrıca bu cephelerde beş adet strüktürel destek yer almaktadır.

Yapının saçağı, iki sıra tuğla kirpi saçak olarak tüm cephede dönmektedir. Büyük kervansarayın üst örtüsü kubbe, diğerininki kubbe ve tonuzdur.

\subsection{Günümüz İşlevi}

Kervansarayın girişi, otel işlevine dönüşümünden sonra değiştirilmiştir. Küçük kervansaray kısmından girildiğinde solda resepsiyon, sağda ise odalara çıkan merdiven yer almaktadır. Giriş kısmından devam edildiğinde solda tuvaletler, yere gömülü teknik mekân ve çeşme bulunmaktadır (Şekil 3.9, 3.10). Teknik mekânın bacası, görüntü kirliliği oluşturmamak için tuvaletlerden birinin içine saklanmıştır.

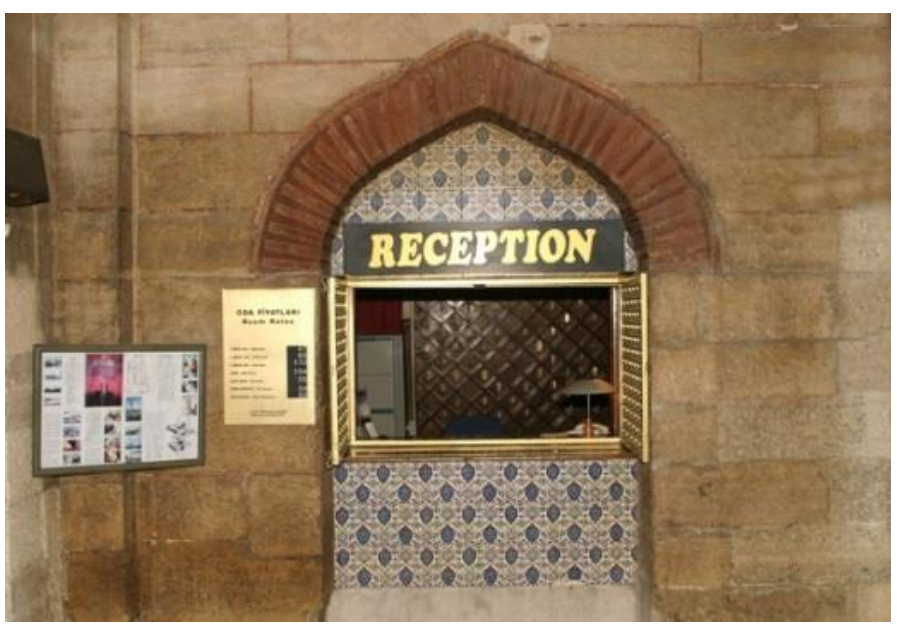

Şekil 3.9. Otelin resepsiyonu (Eraybat, 2011) 


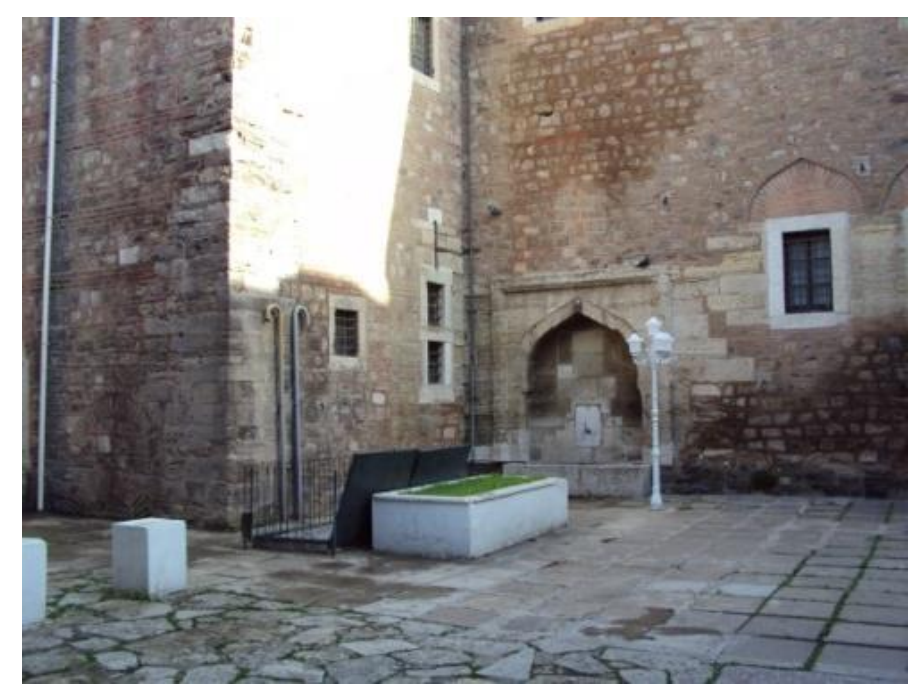

Şekil 3.10. Küçük avludaki teknik mekân girişi ve çeşme

Avlunun güneybatısındaki mekândan içeri girildiğinde sağda toplantı salonu, solda vestiyer ve servis birimleri, tam karşıda bar mekânı mevcuttur. Avlunun güneydoğusundaki mekân, kahvaltı salonu olarak düzenlenmiştir (Şekil 3.11, 3.12) Güzel havalarda, avluya servis açılmaktadır. Kahvaltı salonuyla servis birimlerinin bağlantısı vardır. Servis birimlerine hizmet sağlayan ayrı bir servis girişi bulunmaktadır.

Küçük avludan büyük avlu tarafına geçildiğinde sağdaki ve soldaki mekânlar idari birimler olarak tasarlanmıştır. Avluyu saran revakların arkasındaki diğer mekânlar, yatak odaları ve depolar olmak üzere kurgulanmıştır. Üst kattaki odalar da yatak odaları olarak değerlendirilmiştir. Cepheye bakan yatak odalarının oturma bölümleri de mevcuttur. Doğu köşesinde bulunan oda, hem üst katta hem alt katta kat servisi olarak kullanılmaktadır.

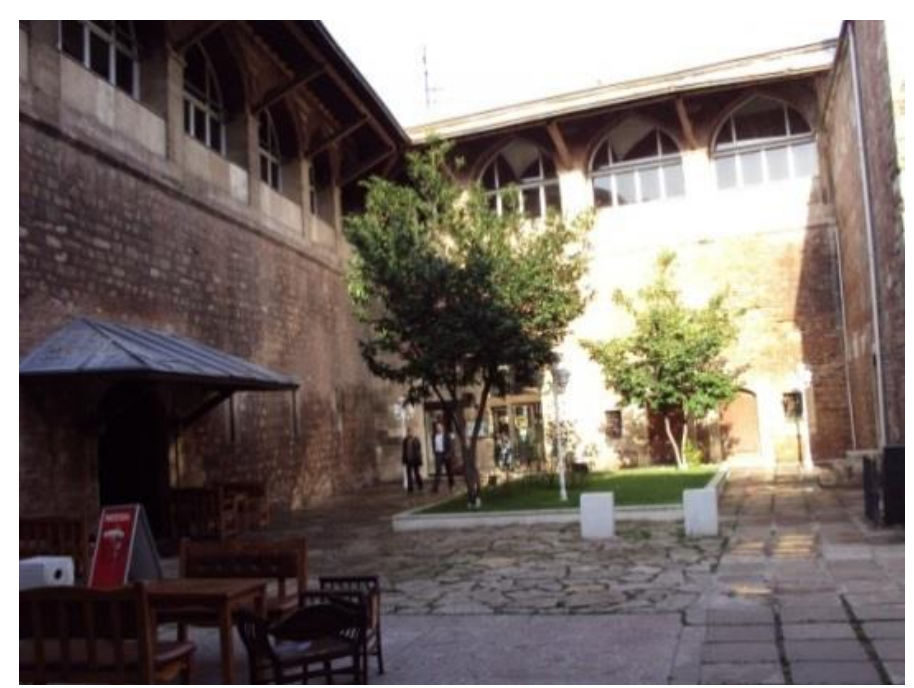

Şekil 3.11. Rüstempaşa Kervansaray Otel'in küçük avlusu 


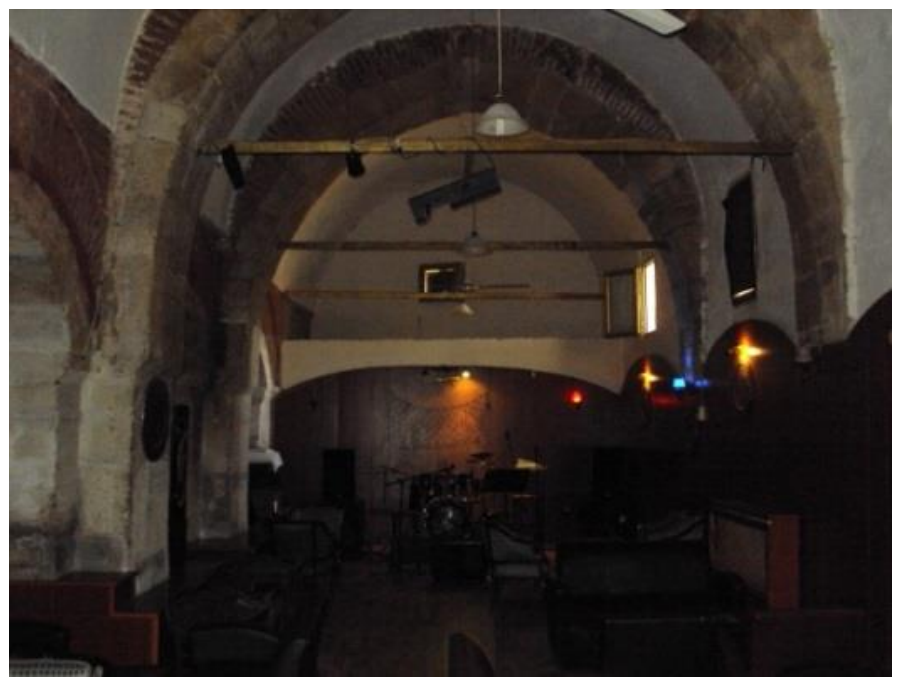

Şekil 3.12. Otelin barı

Üst katta batı köşesinde, her iki bloktan da kullanılabilen hamam ve duşlar tasarlanmıştır. Küçük avluya bakan revaklı galeri cam ve metal çerçeveyle kapatılmış olup koridor haline getirilmiştir. Yatak odaları bu koridorun etrafına dizilmiştir. Bu katta müdüriyet, depo ve tuvalet de yer almaktadır (Şekil 3.13, $3.14,3.15,3.16,3.17)$.
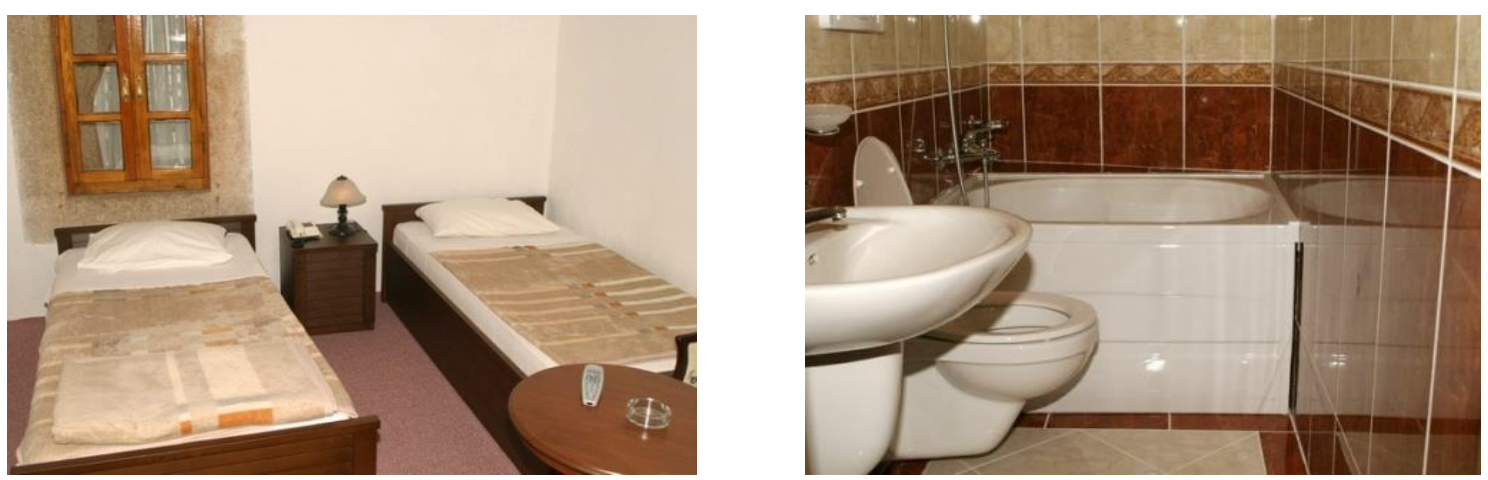

Şekil 3.13. Otelin yatak odası ve banyosu (Eraybat, 2011) 


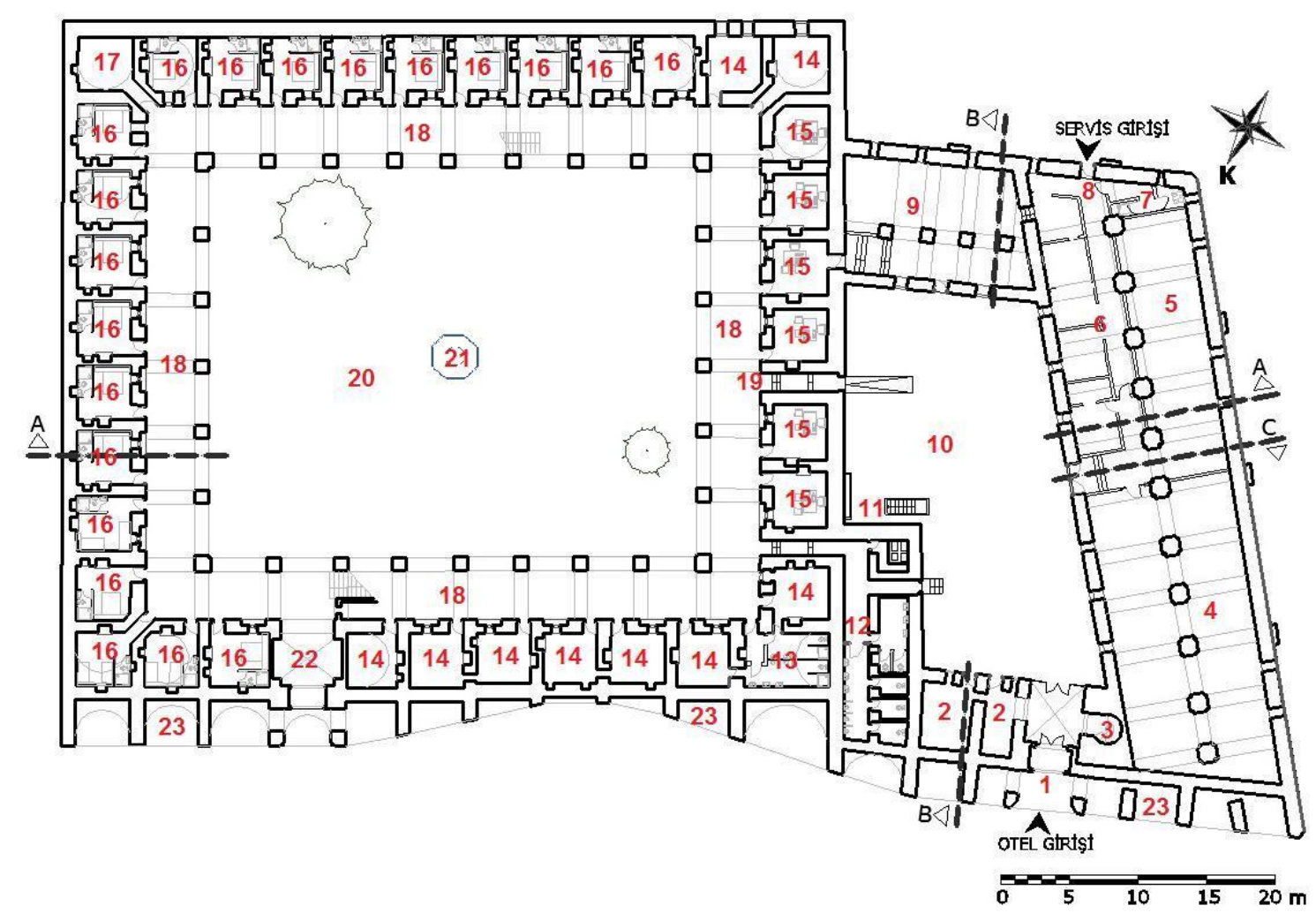
1- Giriş holü
2- Resepsiyon
3- Merdiven
4- Toplantı Salonu
5- Bar
6- Servis Birimleri
7- Islak hacim/depo
8- Servis holü
9- Kahvaltı salonu
10- Küçük avlu
11- Teknik mekân
12- Tuvaletler
13- Personel tuvalet
14- Depolar
17- Kat servisi
18- Revaklar
15- İdari birimler 16- Yatak odaları
21- Şadırvan
22- Giriş holü
19- Geçit
20- Büyük Avlu
23- Dükkânlar

Şekil 3.14. Rüstempaşa Kervansaray Otel'in zemin kat planı (Çakırlar, 1974; Eraybat, 2011; T.Ü. Rölöve Arşivi, 1986) 


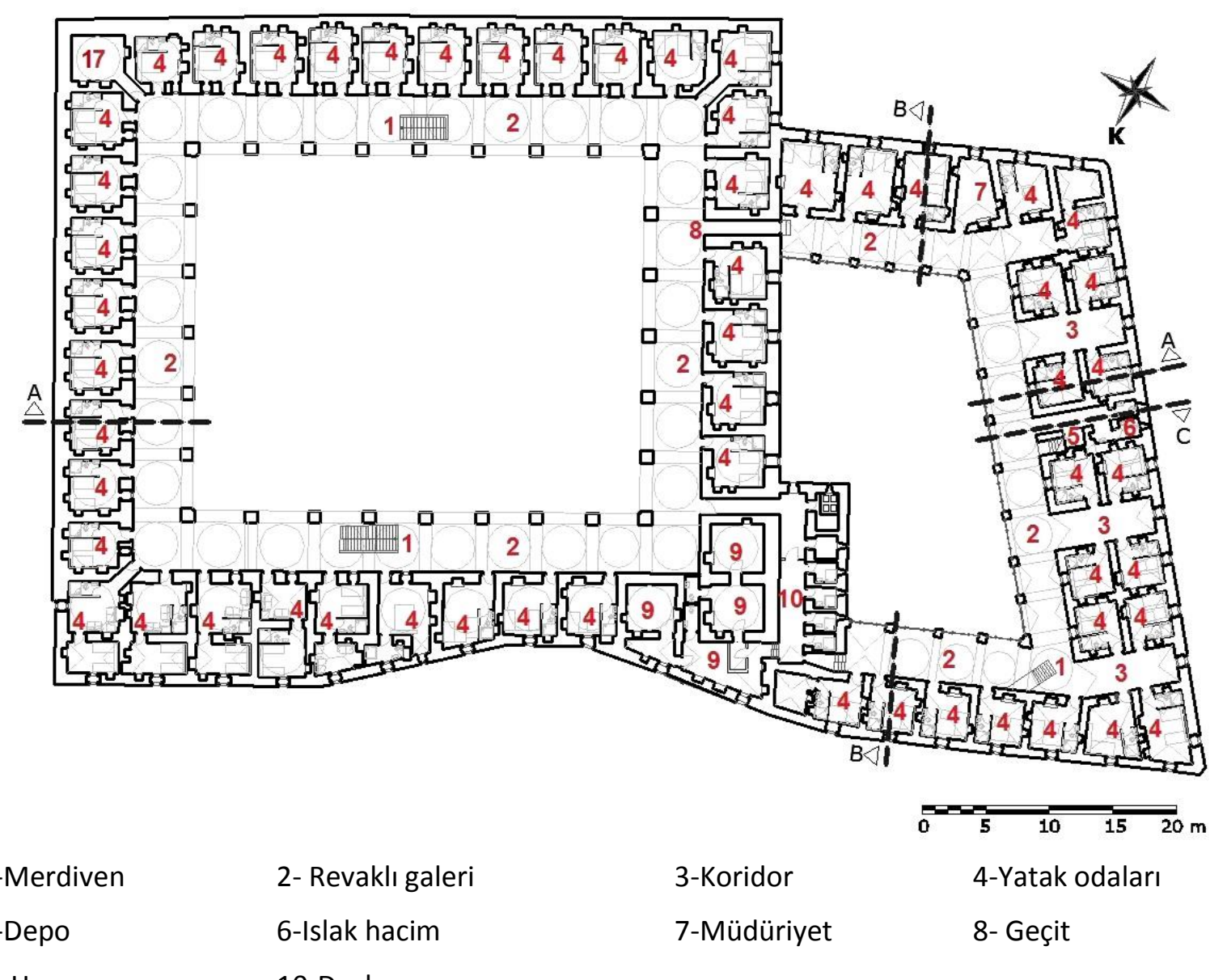

9- Hamam ve soyunma 10 -Duşlar

Şekil 3.15. Rüstempaşa Kervansaray Otel'in üst kat planı (Çakırlar, 1974; Eraybat, 2011).

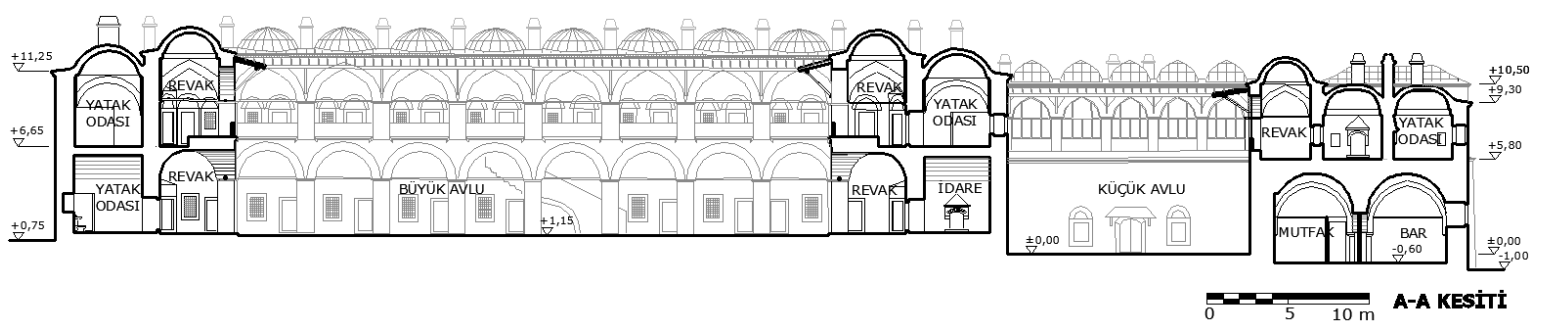

Şekil 3.16. Rüstempaşa Kervansaray Otel'in A-A Kesiti (Eraybat, 2011; TÜ. Rölöve Arşivi, 1986; Ülgen, 1948)

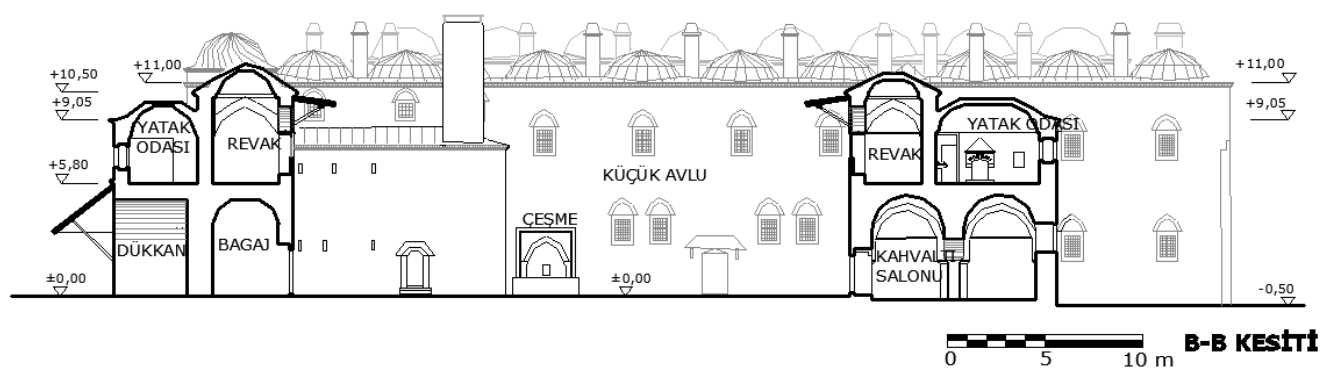

Şekil 3.17. Rüstempaşa Kervansaray Otel'in B-B Kesiti (Eraybat, 2011; TÜ. Rölöve Arşivi, 1986; Ülgen, 1948) 


\subsection{Yeni İşlevin Analizi}

Bir yapıya yeni bir işlev verirken yapının konumu, mekânsal oluşumu (tek bir hacim, tekrarlanan hacim, karmaşık plan şeması), mekânların boyutları, mekânların işlevsel ilişkileri önem kazanmaktadır (Altınoluk, 1998). Bir işlevin yapıya uygunluğunu belirlemek için bu dört faktörün ele alınması gerekmektedir. Bunlara ek olarak intiyaç programı belirlenerek yeni işlevin gereklilikleri de tespit edilmelidir.

Otel işlevinin kervansaray için uygun olup olmadığını araştırabilmek amacıyla öncelikle küçük ölçekli bir otelde bulunması gereken mekânlar belirlenmiş ve kervansaray işlevindeki mekânların otel işlevine geçişte hangi mekânlara dönüştürüldüğü tespit edilmiştir. Daha sonra otel işlevinin konum, mekânsal elverişlilik, mekânsal gereklilik, mekânlar arası ilişki kurgusu açısından olumlu ve olumsuz yönleri irdelenmiş ve değerlendirilmiştir. Otel işlevindeki mekanların boyut ve kapasite yeterliliği hakkında fikir sahibi olabilmek için çeşitli literatür taramaları yapılarak kriterler belirlenmiştir. Belirlenen kriterlere göre değerlendirme yapılmıştır. Tüm veriler tablo haline getirilip aşă̆ıda sunulmuştur (Çizelge 3.1).

Çizelge 3.1. Rüstempaşa Kervansarayı́nın eski ve yeni işlevi

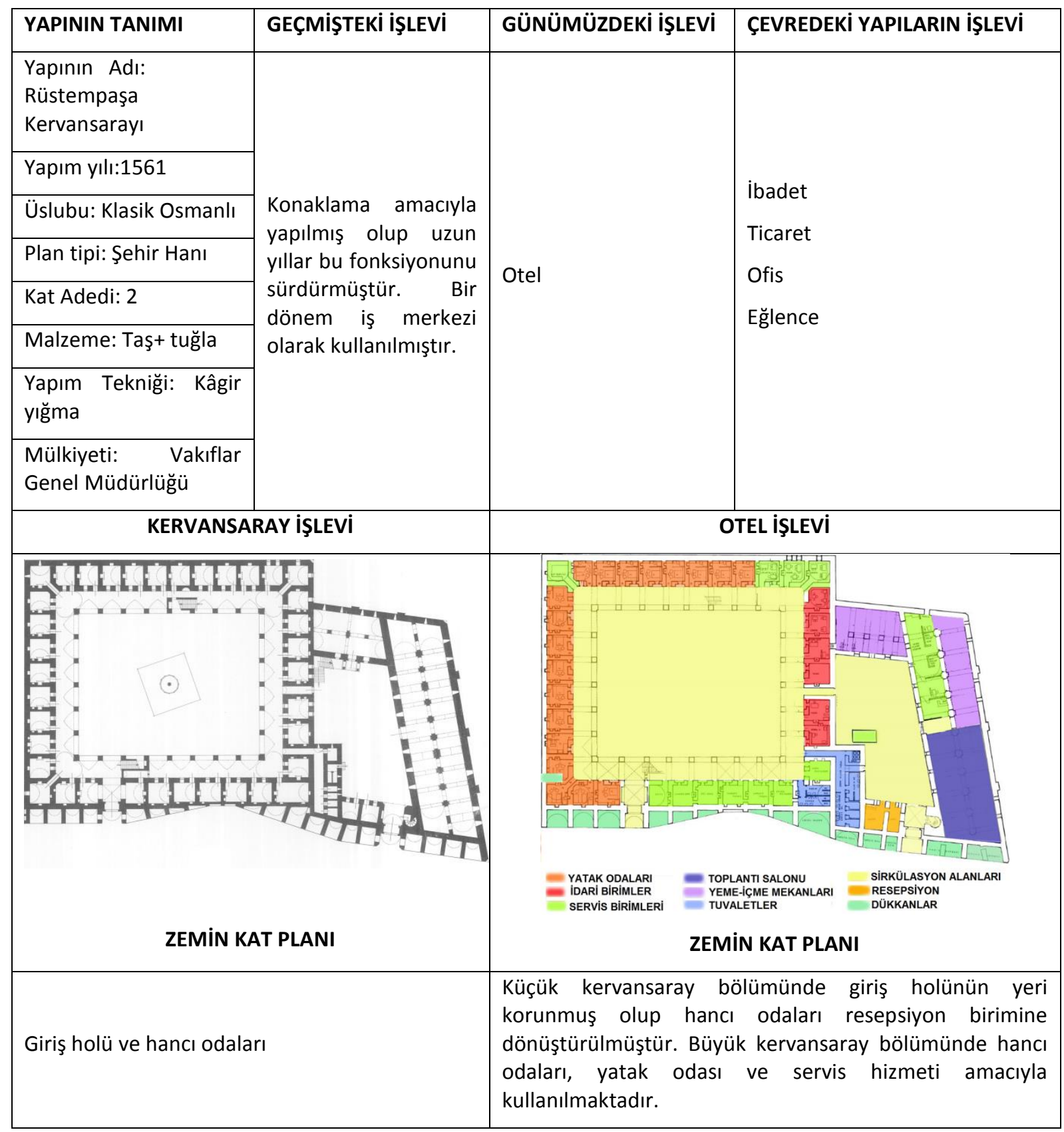




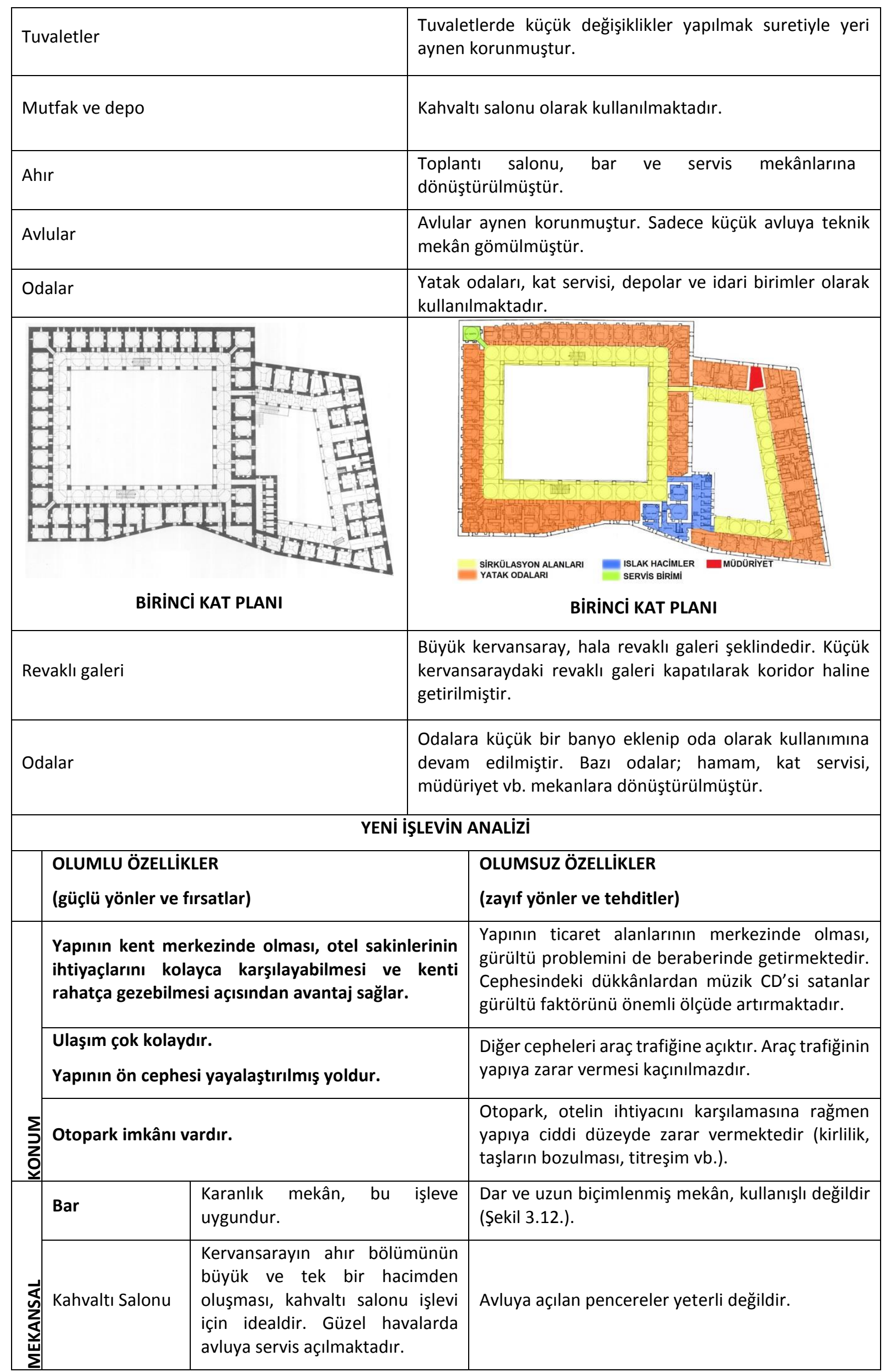




\begin{tabular}{|c|c|c|c|}
\hline & Toplantı Salon & $\begin{array}{l}\text { Otelde böyle bir mekânın olması, } \\
\text { otelin konaklama dışında da } \\
\text { kullanılmasına imkân tanır. }\end{array}$ & $\begin{array}{l}\text { Payeli olduğundan toplantı için uygun bir mekan } \\
\text { değildir. } \\
\text { Bir fuayeye intiyaç duyulabilir. }\end{array}$ \\
\hline & Servis Mekânları & $\begin{array}{l}\text { Kahvaltı salonu ve bar arasında } \\
\text { yer alan servis birimlerinin yeri } \\
\text { uygundur. }\end{array}$ & $\begin{array}{l}\text { Mekânsal dönüşüm aşamasında tesisatın } \\
\text { kurulumu yapının özgünlük değerine zarar } \\
\text { vermiştir. }\end{array}$ \\
\hline & Servis Girişi & $\begin{array}{l}\text { Servis girişinin yeri uygundur. } \\
\text { Servis birimlerinin ihtiyacını } \\
\text { karşılamaktadır. }\end{array}$ & Yapıya sonradan yapılmış müdahaledir. \\
\hline & Teknik Mekân & $\begin{array}{l}\text { Küçük avlunun uygun bir } \\
\text { köşesine gömülmüştür. Böylece } \\
\text { teknik mekân gizlenmiştir. }\end{array}$ & $\begin{array}{l}\text { Sürekli açık duran kapı, hem kontrolsüzlük hem de } \\
\text { kötü bir görüntü oluşturmaktadır. } \\
\text { Teknik mekâna inen boşluğun etrafına yapılan } \\
\text { koruma amaçlı parmaklık ve mekânın } \\
\text { havalandırması, yapının tarihi dokusuna uygun, } \\
\text { estetik bir çözüm değildir. }\end{array}$ \\
\hline & Yatak Odaları & $\begin{array}{l}\text { Sıra dizi halinde tekrarlanan } \\
\text { hacimler, otel işlevinde de yatak } \\
\text { odası olarak kullanmaya } \\
\text { elverişlidir. }\end{array}$ & $\begin{array}{l}\text { Odaların adaptasyonu için tesisat kurulumu } \\
\text { gereklidir. Ancak tarihi yapıların tesisat çözümü } \\
\text { oldukça problemlidir. } \\
\text { Odalardan bazıları iyi ışık almamaktadır. }\end{array}$ \\
\hline & İdari Birimler & 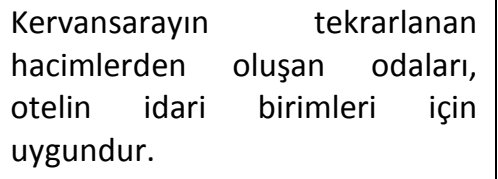 & $\begin{array}{l}\text { İdari birimlerin, iki avluyu birbirine bağlayan } \\
\text { geçitle kesilmesi, ofislerde sese neden olabilir. }\end{array}$ \\
\hline & Avlular & $\begin{array}{l}\text { Avlular, aynen korunmuş olup çok } \\
\text { fonksiyonlu mekânlara } \\
\text { dönüşmüştür. } \\
\text { Büyük kervansarayda otel } \\
\text { müşterisi olmadığında kermes, } \\
\text { sergi vb. işler için büyük avlu } \\
\text { kiralanabilir. }\end{array}$ & $\begin{array}{l}\text { Avlunun açık olması, kışın problem oluşturabilir. } \\
\text { Avluların düğün, davet gibi organizasyonlarda } \\
\text { kullanılması, gürültü probleminden ötürü otel } \\
\text { sakinlerini rahatsız etmektedir. }\end{array}$ \\
\hline & Koridorlar & $\begin{array}{l}\text { Küçük avlunun üst katındaki } \\
\text { revaklı galerinin cam ile } \\
\text { kapatılması, odalara sesin geçişini } \\
\text { azaltmaktadır. Böylelikle iklim } \\
\text { şartlarına uygun korunaklı bir } \\
\text { koridor oluşmaktadır. }\end{array}$ & $\begin{array}{l}\text { Büyük avluda bulunan yarı açık revaklar, iklimsel } \\
\text { konfor koşullarının sağlanamamasına ve avluda } \\
\text { gerçekleştirilen etkinliklerde ortaya çıkan sesten } \\
\text { müşterilerin rahatsız olmasına neden olmaktadır. }\end{array}$ \\
\hline : & Tuvaletler & 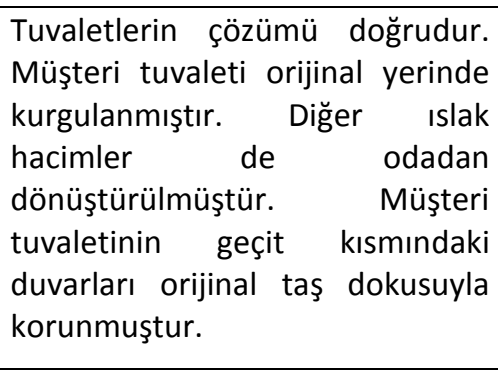 & $\begin{array}{l}\text { Mekânsal dönüşüm aşamasında tesisat ihtiyacı } \\
\text { oluşmuştur. Tesisat sisteminin kurulumu yapının } \\
\text { özgünlügüne zarar vermiştir. } \\
\text { Orijinal zemin döşemesi yok olmuştur. Zemin ve } \\
\text { duvarlar yapının tarihi dokusuyla uyumsuz fayans } \\
\text { malzemeyle döşenmiştir. }\end{array}$ \\
\hline 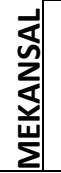 & Bacalar & $\begin{array}{l}\text { Tuvaletteki mekânın biri iptal } \\
\text { edilip kalorifer dairesinin bacası } \\
\text { olarak kullanılmıştır. Odalardaki } \\
\text { banyoların havalıkları yandaki }\end{array}$ & $\begin{array}{l}\text { Bacaya dönüştürülmek üzere tuvaletlerden birine } \\
\text { müdahale edilmiştir. }\end{array}$ \\
\hline
\end{tabular}




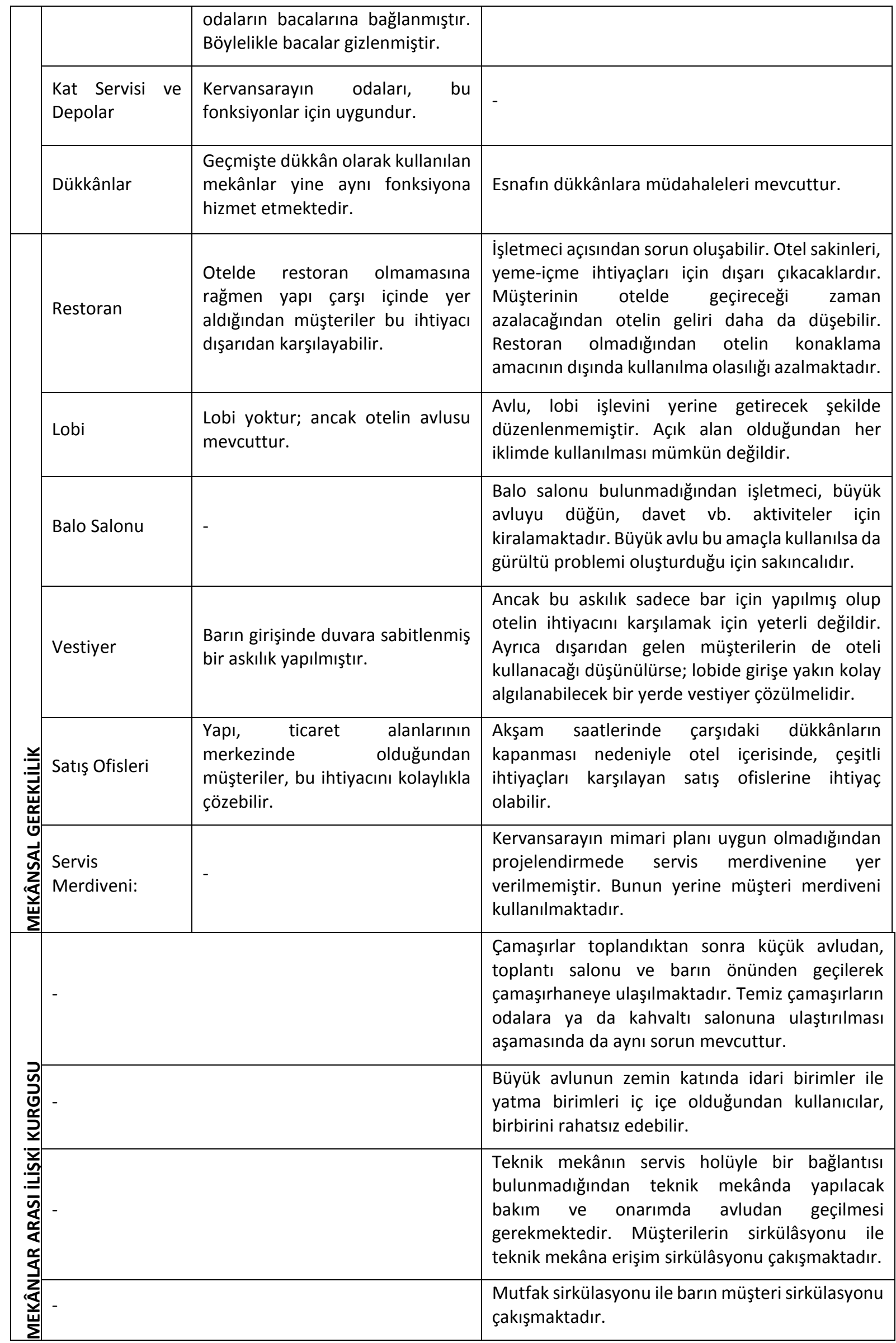




\begin{tabular}{|l|l|l|}
\hline- & $\begin{array}{l}\text { Büyük avludaki depolar ile yatak odalarının aynı } \\
\text { yerde olması buradaki servis işlemlerini } \\
\text { müşterilerin görmesine neden olmaktadır. }\end{array}$ \\
\hline$-\quad \begin{array}{l}\text { Üst kata servis için müşterilerin kullandığı } \\
\text { merdiven ve koridor kullanımaktadır. }\end{array}$ \\
\hline $\begin{array}{l}\text { Servis girişinin servis birimleriyle ilişkisi doğru } \\
\text { kurgulanmışır. }\end{array}$ & - \\
\hline $\begin{array}{l}\text { Servis birimlerinin kahvaltı salonuyla doğrudan } \\
\text { bağlantısının olması doğru bir çözümdür. }\end{array}$ & - \\
\hline $\begin{array}{l}\text { Yatma birimlerini, kat olarak sosyal birimlerinden, } \\
\text { servis birimlerinden ve idari birimlerden ayırmak, } \\
\text { mahremiyeti sağlamak açısından doğru bir karardır. }\end{array}$ & $\begin{array}{l}\text { Sadece büyük kervansaray tarafında yatma } \\
\text { birimleriyle diğer birimler bir aradadır. Işletmeci, } \\
\text { doldurmaktaük kervansaray tarafındaki odaları }\end{array}$ \\
\hline
\end{tabular}

Yapının mevcut mekân boyutlarının, otel işlevini sağlıklı bir şekilde yerine getirmeye yeterli olup olmadığının belirlenmesi için ilgili yönetmeliklerden ve literatür taramasından yararlanmak gerekmektedir. Turizm Tesislerinin Belgelendirilmesine ve Niteliklerine İlişkin Yönetmelik'e göre Rüstempaşa Kervansaray Otel, “özel tesisler” sınıfında yer almaktadır. Yönetmelik'te bu kategorideki turizm tesisleri için mimari bir sınırlama bulunmayıp sadece işletmeye yönelik sınırlamalar bulunmaktadır.

Otellerin mekân boyutları ve kapasitelerine ilişkin değişik kaynaklarda çok çeşitli standartlar bulunmaktadır. Küçük ölçekli bir şehir içi otelinin (iki ya da üç yıldızlı bir otel) kapasitesi esas alınarak gerekli mekân boyutları saptanmış ve aşağıda tablo haline getirilmiştir (Çizelge 3.2).

Çizelge 3.2. Boyutsal yeterliliğinin araştırılması

\begin{tabular}{|c|c|c|c|}
\hline Mekân İsmi & $\begin{array}{l}\text { Mevcut Mekânın } \\
\text { Boyutları }\end{array}$ & $\begin{array}{l}\text { Minimum Düzeyde } \\
\text { Gerekli Mekânsal } \\
\text { Boyutlar (Doğu, 1994; } \\
\text { Apaydın 2007; } \\
\text { Lawson, 1998; Ransley } \\
\text { ve Ingram, 2004) }\end{array}$ & Açıklama \\
\hline Otopark & $\begin{array}{l}\text { Yaklaşık } 19 \text { araçlık park } \\
\text { yeri mevcuttur. }\end{array}$ & $\begin{array}{l}19-37 \text { araçlık park yeri } \\
470 \mathrm{~m}^{2}\end{array}$ & $\begin{array}{l}\text { Arka tarafında ayrıca özel bir } \\
\text { otopark alanı vardır. Otoparka } \\
\text { ihtiyaç yoktur. }\end{array}$ \\
\hline Resepsiyon & $\begin{array}{l}1.65 \mathrm{~m} \text { (uzunluk) } \\
11 \mathrm{~m}^{2} \text { (alan) }\end{array}$ & $\begin{array}{l}3-5.25 \mathrm{~m} \text { (uzunluk) } \\
9.3-15 \mathrm{~m}^{2} \text { (alan) }\end{array}$ & $\begin{array}{l}\text { Yetersiz } \\
\text { Yeterli }\end{array}$ \\
\hline Yatak Odası & $14-23 m^{2}$ & $14.5-35 \mathrm{~m}^{2}$ & $\begin{array}{l}\text { Odalar günümüz şartlarından } \\
\text { küçük olsa da kabul edilebilir } \\
\text { boyutlardadır. Boyutlar, suit oda } \\
\text { için uygun değildir. } \\
\text { Odaların boyutları küçük } \\
\text { olduğundan banyoda } 1.20 \mathrm{~m} \\
\text { uzunluğunda yarım oturma } \\
\text { küvet kullanıııışır (Şekil 3.13). }\end{array}$ \\
\hline Toplantı Salonu & $227 \mathrm{~m}^{2}$ & $225-337.5 m^{2}$ & Yeterli \\
\hline Bar & $97 \mathrm{~m}^{2}$ & $30-105 m^{2}$ & Yeterli \\
\hline $\begin{array}{l}\text { Kahvaltı } \\
\text { Salonu* }\end{array}$ & $111 \mathrm{~m}^{2}$ & $\begin{array}{l}75-120 \mathrm{~m}^{2} \\
\text { kişilik) }\end{array}$ & Yeterli \\
\hline Mutfak & $88 \mathrm{~m}^{2}$ & $50-55 m^{2}$ & Yetersiz \\
\hline
\end{tabular}




\begin{tabular}{|l|l|l|l|}
\hline Çamaşırhane & $48.75-59.25 \mathrm{~m}^{2}$ & \\
\hline $\begin{array}{l}\text { Personel duş, } \\
\text { WC, soyunma } \\
\text { vb. }\end{array}$ & $63.5 \mathrm{~m}^{2}$ & $45-97.5 \mathrm{~m}^{2}$ & Yeterli \\
\hline $\begin{array}{l}\text { Tuvaletler } \\
\text { (Müşteri) }\end{array}$ & $49 \mathrm{~m}^{2}$ & $41 \mathrm{~m}^{2}$ & Yeterli \\
\hline $\begin{array}{l}\text { Idari Birimler } \\
\text { Depolar } \\
\text { (toplam) }\end{array}$ & $94 \mathrm{~m}^{2}$ & $22.5-67.5 \mathrm{~m}^{2}$ & Yeterli \\
\hline $\begin{array}{l}\text { Sirkülasyon } \\
\text { Alanları } \\
\text { (toplam) }\end{array}$ & $1135 \mathrm{~m}^{2}$ & $47.3-72 \mathrm{~m}^{2}$ & Yeterli \\
\hline Geçitler & $\begin{array}{l}\text { Zemin Kat } 1.36 \mathrm{~m} \\
\text { Üst Kat } 1.2 \mathrm{~m}\end{array}$ & $1.6-2.2 \mathrm{~m}$ & $\begin{array}{l}\text { Yoğunluğu karşılamaya yetecek } \\
\text { boyutlardadır. } \\
\text { Uzun koridor, } \\
\text { zorlaştırabilir. }\end{array}$ \\
\hline
\end{tabular}

*Kahvaltı salonu için belirlenmiş net bir değer olmadığından küçük otellerin restoran tasarımında kullanılan değerler alınmıştır.

\section{Değerlendirme ve Sonuç}

Rüstempaşa Kervansaray Otel projesinin, Ağa Han Mimarlık Ödülü’ne layık görülmesinde, konaklama fonksiyonuyla birlikte koruma eyleminin yoğrulması etkili olmuştur. Fakat sosyal, kültürel ve teknolojik değişimlerin etkisiyle konfor kavramı, kullanıcı gereksinimleri ve konaklama anlayışı da değişime uğramıştır. Kervansaray yeniden işlevlendirilmiş olmasına rağmen değişimin sürekliliği zamanla yapının işlevsel olarak eskimesine neden olmuştur.

Rüstempaşa Kervansarayı'na verilen yeni işlev incelendiğinde, konumun otel işlevi için oldukça uygun olduğu söylenebilir. Konumla ilgili yukarıda belirtilen bazı olumsuzluklar olmasına rağmen bu sorunlar basit çözümlerle ortadan kaldırılabilir.

Çalışmanın sonucunda, Rüstempaşa Kervansaray Otel'de bazı mekânların yer almadığı, bazılarına verilen işlevin mekânsal olarak elverişli olmadığı ortaya çıkmıştır.

Mekânsal elverişlilik açısından değerlendirildiğinde, bar ve toplantı salonu olarak kullanılan mekânlar, bu işlevler için uygun değildir. Kahvaltı salonu ve bazı odalar da iyi ışık almamaktadır. Avlu ise düğün, davet gibi organizasyonlarda kullanılmaya elverişli değildir.

Günümüz otelciliğinde, otelin kalbi olarak nitelendirilen ve verdiği mesaj yönünden otelin en prestijli mekânı olarak kabul edilen lobi, Rüstempaşa Kervansaray Otel'de bulunmamaktadır. Bu mekânın olmaması, bir yandan işlevsel aksaklıklara neden olurken öte yandan otelin müşteriler üzerinde bıraktığı ilk izlenim bakımından olumsuz etki oluşturmaktadır.

Lobinin dışında balo salonu, satış ofisleri, restoran, vestiyer ve servis merdiveni de eksiktir. Balo salonu, satış ofisleri ve restoran ihtiyacı, otel dışından da karşılanabildiği için zaruret arz etmemektedir. Balo salonu ve restoran olmadığı için vestiyer de önemini yitirmiştir. Ancak servis merdiveninin olmaması, işlev çakışmalarına neden olmaktadır. Özellikle müşteri ve servis sirkülasyonun çakışması otel işlevi için sorun oluşturmaktadır.

Resepsiyonun alanı yeterli olmasına rağmen bankosunun uzunluğunun yeterli olmadığı görülmektedir. Bu durum tıpkı lobideki gibi otelin prestij öğelerinden biri olan resepsiyonun müşteri üzerinde oluşturduğu etkiyi zayıflatmaktadır. Bunun dışında mutfak ve çamaşırhanenin yer aldığı servis birimi, işlevini sağlıklı bir şekilde gerçekleştirmeye uygun boyutta değildir. Yatak odalarının boyutları, minimum düzeyde standartların alt sınırını sağlamasına rağmen yeni otellerin odalarından daha 
küçüktür. Koridor görevi üstlenen revaklı galerilerin alanları, normalden fazladır; ancak yapının orijinal geçitlerinin genişliği, normal bir koridor genişliğinden dardır.

Yeniden işlevlendirilen kervansarayda işlevsel aksaklıkların yanı sıra, işletme sorunları da mevcuttur. İşletme sorunları, müşteri için çoğu zaman işlevsel aksaklıklardan daha rahatsız edici olmaktadır (Örneğin, oda temizliği, mobilyaların eskimesi ve yapıyla uyumsuzluğu, kahvaltının yetersiz bulunması, odanın ısıtma ve soğutma sorunu gibi). Bu sebeple müşterilerin memnuniyet düzeyi düşmektedir.

Kervansarayın kaybettiği prestiji yeniden kazanabilmesi için iyi bir yenileme projesine ihtiyaç vardır. Bu proje, bazı yapısal ek ve değişikliklerle otel işlevinin eksikliklerini gidermelidir. Bununla birlikte yapının konservasyon ve restorasyonunu da içermelidir. Kurumsal imajı oluşturmanın en önemli kısımlarından biri olan işletmeye yönelik sorunların da ortadan kaldırılması gerekmektedir.

Tüm olumsuzluklara rağmen yeni işlevin olumlu yönleri de mevcuttur. Geçmişte konaklama işlevine hizmet eden kervansarayın günümüzde de aynı amaçla kullanılması, geçmiş ve günümüz arasındaki kavramsal bağlantıyı sağlamaktadır.

Yeni işlevin sağladığı bir diğer fayda, atıl durumdaki yapıların ekonomik geri dönüşüme katkısıdır. Bununla birlikte enerji tüketiminin ve karbon emisyonunun azaltılması yönüyle çevresel katkıları; yapıların tarihi, kültürel, sanatsal değerleri ile toplumsal benliği oluşturan değerlerin gelecek kuşaklara aktarılması yönüyle sosyal ve kültürel katkıları da bulunmaktadır.

Ayrıca sürdürülebilir koruma anlayışının hâkim olduğu günümüzde, yeni işlev, tarihi yapıların yaşatılarak korunması sağlayan ve yapıları yıkılma sürecinden kurtaran bir çözümdür. Geçmişte Edirne'deki birçok han ve kervansarayın kullanım dışı kalması sonucu, terk edildiği ve zamanla yıkıldığı bilinmektedir. Dolayısıyla yeni işlevin bir takım sorunları olsa da bütüncül bakıldığında kervansarayın günümüze kadar ulaşabilmesinde yapının kullanılmasının etkisi olmuştur.

\section{Kaynaklar}

Ahunbay, Z. (2009). Tarihi çevrede koruma ve restorasyon. İstanbul, Türkiye: Yapı Endüstri Merkezi Yayını, ss. 898.

Akçıl, N. Ç. (2008). Rüstem Paşa Kervansarayı-Edirne. Türkiye Diyanet Vakfı İslam Ansiklopedisi, cilt:35, İstanbul, Türkiye: Türkiye Diyanet Vakfı Yayını, ss. 290-291.

Altınoluk, Ü. (1998). Binaların yeniden kullanımı. İstanbul, Türkiye: Yapı Endüstri Merkezi Yayınları, ss. 22.

Apaydın, B. B. (2007). Yapıların otel olarak yeniden kullanım bağlamında mekânsal dönüşümlerinin kavramsal ve kuramsal analizi. Mimar Sinan Üniversitesi, Fen Bilimleri Enstitüsü, İç Mimarlık Ana Bilim Dalı, Sanatta Yeterlilik Tezi, İstanbul, Türkiye, ss.17-225.

Aydın, D. ve Okuyucu, E. Ş. (2009). Yeniden kullanıma adaptasyon ve sosyo-kültürel sürdürülebilirlik bağlamında Afyonkarahisar millet hamamının değerlendirilmesi. Megaron YTÜ Mim. Fak. E-Dergisi, 3(3): 230-243.

Cantay, G. (1988). Kervansaraylar. S. Bayram (Ed.), Mimarbaşı Koca Sinan: Yaşadığı Çağ ve Eserleri, İstanbul, Türkiye: Vakıflar Genel Müdürlüğü Yayını, cilt:1, 369-392.

Cassar, M. (2009). Sustainable heritage: challenges and strategies for the twenty-first century. APT Bulletın: Journal of Preservation Technology, 40(1): 3-11.

Conejos, S., Langston, C. and Smith, J. (2011). Improving the implementation of adaptive reuse strategies for historic buildings. Le Vie dei Mercanti S.A.V.E. HERITAGE: Safeguard of Architectural, Visual, Environmental Heritage, Naples, Italy, Jun. 2011, p.1-10.

Çakırlar, E. (1974). Edirne Rüstempaşa Kervansarayı. Rölöve ve Restorasyon Dergisi, Ankara. Türkiye: Vakıflar Genel Müdürlüğü Yayınları, 1 (1): 129-144.

Doğu, O. (1994). Oteller. İstanbul, Türkiye: Eren Ofset Matbaası, ss. 8-13.

Douglas, J. (2006). Building adaptation. 2nd edition, Edinburgh, UK: Elsevier Butterworth-Heinemann, p.1.

Edirne Belediyesi Arşivi, (2011). 
Eraybat, G. F. (2011). Tarihi konaklama yapılarının doğuşu, gelişimi ve günümüzde çağdaş işlevle değerlendirilmesi: Edirne Rüstempaşa Kervansarayı örneği. Trakya Üniversitesi, Fen Bilimleri Enstitüsü, Mimarlık Anabilim Dalı, Yüksek Lisans Tezi, Edirne, Türkiye, ss.201-207.

Hay, G. J. and Castilla, G. (2006). Object-based image analysis: strengths, weaknesses, opportunities and threats (SWOT). 1st International Conference on Object-based Image Analysis (OBIA 2006), Salzburg University, Salzburg, Austria, 4-5 July 2006, p. 7-10.

Güran, C. (1978). Türk Hanlarının Gelişimi ve İstanbul Hanları Mimarisi. İstanbul: Vakıflar Genel Müd. Yayını, s.1.

Kincaid, D. (2002). Adapting buildings for changing uses. New York, USA: Spon Press, p.3-4.

Kuban, D. (2000). Tarihi çevre korumanın mimarlık boyutu kuram ve uygulama. İstanbul, Türkiye: Yapı Endüstrisi Yayını, ss.39-203.

Kuban, D. (2007). “Osmanlı mimarisi. İstanbul, Türkiye: Yapı Endüstrisi Yayını, ss.75-408.

Küçükkaya, G. A. (1990). Mimar Sinan Dönemi İstanbul-Belgrad arası menzil yapıları hakkında bir deneme. Vakıflar Dergisi, 21: 183-254.

Langston, C. (2008). The sustainability implications of building adaptive reuse. CRIOCM 2008 International Research Symposium on Advancement of Construction Management and Real Estate, Beijing, China. Nov.2008.

Langston, C. and Shen, L. Y. (2007). Application of the Adaptive Reuse Potential Model in Hong Kong: A Case Study of Lui Seng Chun. International Journal of Strategic Property Management, 11: 193- 207.

Lawson, F. R. (1998). Hotels and resorts: planning, design, and refurbishment. 2nd edition, Oxford, UK: Elsevier Butterworth-Heinemann, p.118-288.

Mıhlayanlar, E. ve Yardımlı, S. (2006). Edirne'nin Rüstempaşa Kervansarayı ve çevresinde hava kirliğine bağı bozulmalar. Yöre Aylık Kültür Dergisi, 73: 3-14.

Onur, O. (2006). XVI'dan XX.yüzyıla belgelerle Edirne. İstanbul, Türkiye: Edirne Valiliği Yayınları, ss. 170-180.

Pehlivan, E. (2010). Doğu Trakya'da Roma Dönemi Yolları. Trakya Üniversitesi, Sosyal Bilimleri Enstitüsü, Arkeoloji Anabilim Dalı, Yüksek Lisans Tezi, Edirne, Türkiye.

Ransley, J. and Ingram, H. (2004). Developing hospitality properties and facilities. 2nd edition, Oxford, UK: Elsevier Butterworth-Heinemann, p.197-221.

Süman, Ş. L. (2000). Edirne'de 15. ve 16. yüzyıl Osmanlı Dönemi han ve kervansaraylarının mimarisi ve onarım sorunları. Trakya Üniversitesi, Fen Bilimleri Enstitüsü, Mimarlık Anabilim Dalı, Yüksek Lisans Tezi, Edirne, Türkiye, ss.31-44.

T.Ü. Rölöve Arşivi, (1986). Edirne Rüstem Paşa Kervansarayı Çizimleri.

Ülgen, A. S. (1948). Edirne Rüstem Paşa Kervansarayı Genel Durum Planı/Zemin Kat Planı/ Üst Kat Planı/Kesitler, Levha 226-231.

Yung, E. H. K. and Chan, E. H. W. (2012). Implementation challenges to the adaptive reuse of heritage buildings: towards the goals of sustainable*, low carbon cities. Habitat International, 36. 352-361. 